\title{
Omalizumab in chronic spontaneous and inducible urticaria: a 9 year retrospective study in Portugal
}

\author{
${ }^{1}$ Immunoallergology Department, Santa Maria Hospital, Centro Hospitalar Lisboa Norte, Lisbon, Portugal \\ ${ }^{2}$ Universitary Center of Immunoalergology, Medicine Faculty of Lisbon, Lisbon, Portugal
}

\section{KEY WORDS}

omalizumab; anti-IgE; chronic spontaneous urticaria; chronic inducible urticaria; quality of life

\section{Corresponding author \\ João Marcelino \\ Serviço de Imunoalergologia, Piso 7 \\ Hospital de Santa Maria \\ Avenida Prof. Egas Moniz \\ 1649-035 Lisbon, Portugal \\ E-mail: JLAM_1987@sapo.pt}

Doi

10.23822/EurAnnACI.1764-1489.51

\begin{abstract}
Summary
Objective. Describe the safety and long-term use of omalizumab in chronic urticaria (CU), both spontaneous (CSU) and inducible (CIndU). Methods. Retrospective chart-review (2006-15) of CU patients treated with omalizumab for $\geq 6$ months. Statistical analyses: descriptive statistics, Mann-Whitney, generalized linear models. Results. 23 patients with CSU (3 men), 3 with CIndU (2 men). Generalized linear models showed UAS reduction per omalizumab administration of $16 \%$ in CIndU and CSU (both $p<0.001$ ) and UAS7, of $15 \%$ in CIndU, and 20\% in CSU (both $p<0.001)$. DLQI score at baseline had a median of 19 (CIndU and CSU) and after omalizumab a median of O (in both). Seven CSU patients stopped omalizumab and remain asymptomatic. No side-effects were observed. Conclusion. Omalizumab is safe and efficacious in CU. Stopping omalizumab can be tried, as some patients achieve remission.
\end{abstract}

\begin{abstract}
Abbreviations
$\mathrm{CU}$, chronic urticaria; CSU, chronic spontaneous urticaria; CIndU, chronic inducible urticaria; QoL, quality of life; CUQoL, chronic urticaria quality of life; ASST, autologous serum skin test; DLQI, dermatology life quality index; UAS, urticaria activity score; nsAH, non-sedating $\mathrm{H}_{1}$-antihistamines
\end{abstract}

\section{Introduction}

Chronic urticaria (CU) is a debilitating disease characterized by wheals, flares and/or angioedema that recur or last longer than 6 weeks. CU is subdivided into spontaneous (when lesions recur without the need of a stimulus) and inducible (when there is an identifiable trigger) (1).

Chronic spontaneous urticaria (CSU) affects 0.5 to $1 \%$ of the population, with a female predominance $(2: 1)$ and a peak in- cidence between the ages of 20 and 40 (2). This high prevalence makes the effects of CU in patients' quality of life (QoL) relevant. O'Donnell et al. showed CSU patients suffer similar QoL impairment to patients with severe coronary artery disease awaiting for bypass surgery (3).

Current EAACI/GA(2)LEN/EDF/WAO guidelines therapy's aim is complete symptom resolution, beginning with non-sedating $\mathrm{H}_{1}$-antihistamines (nsAH), which can be increased up to four-fold (1). However, less than $50 \%$ of patients respond to the standard dose, and $1 / 4$ to $1 / 3$ remain symptomatic after the fourfold increase (2). The high number of still symptomatic patients explains why third line therapies are so important.

Very thorough placebo-controlled clinical trials (ASTERIA I, II and GLACIAL) have shown clear improvement of CSU with omalizumab; but very little is known concerning its long-term 
effects and efficacy (3-5). Omalizumab is currently approved in CSU, but has also been used with good results in many types of chronic inducible urticaria (CIndU) (6-16).

The main objective is to describe the clinical characteristics of CU patients treated with omalizumab at our Immunoallergology Department. Other objectives include evaluating the efficacy and long-term safety of omalizumab and the feasibility of stopping omalizumab.

\section{Materials and methods}

We performed a retrospective chart-review study, June 2006 July 2015, of adults with CU treated with omalizumab at our Immunoallergology Department; with a minimum of 6 months of treatment. All patients who begin omalizumab for chronic urticaria, do so for a minimum period of 6 months. This time limit was implemented in our Immunoallergology Department so that a correct assessment of a patient's response or lack of response to omalizumab could be made and, subsequently, the decision to continue or stop omalizumab. Because all patients take omalizumab for this 6-month "trial" period, no patient stopped omalizumab before this 6-month time limit due to lack of response. Therefore, no patient who could have been classified as non-responder was excluded from this study due to this time limit.

Patients were characterized according to demographic data (gender, presence of atopic comorbidities, age of CU onset and omalizumab's initiation, $\mathrm{CU}$ duration), type of $\mathrm{CU}$, previous failed therapies, current therapies, omalizumab initial dose, omalizumab therapy duration baseline total serum IgE, autologous serum skin test (ASST) and anti-thyroid antibodies.

Patients response to omalizumab was analyzed using validated patient reported questionnaires: urticaria activity score, UAS and UAS7, taken at baseline and at each visit for omalizumab administration; and Dermatology Life Quality Index, DLQI, taken at baseline and 6-12 months after beginning of omalizumab.

Stepping down of medication was mostly made as follows: all patients started omalizumab as an add-on therapy. When control was achieved (defined as UAS7 $\leq 6$ at the time of omalizumab administration) stepping down occurred in the following order: oral corticosteroids; H2-antihistamines; leukotriene receptor antagonist (except for those taking it for atopic comorbidities); nsAH (4 tablets/day --> 2 tablets/day --> 1 tablet/day --> SOS [meaning as rescue medication for transient exacerbations]). Patients were categorized (on July 2015) according to their response to omalizumab (classification adapted from Har et al) (17) as: 1, complete responders who only required SOS nsAH and omalizumab to maintain UAS7 $\leq 6$ (includes patients on montelukast for atopic comorbidities); 2, partial responders who required daily medication other than omalizumab to main- tain control; 3 , non-responders who began omalizumab but had no improvement.

Complete responders were additionally categorized according to their response to tapering off omalizumab: 1 , non omalizumab-dependent who stopped omalizumab and maintained CU control; 2, omalizumab-dependent who had flares when tried to increase the time intervals between administrations or stop omalizumab.

Tapering off omalizumab was as follows: if UAS7 $\leq 6$ was maintained between administrations, the time intervals between administrations was increased from every 4 weeks to every 5 , then every 6 and then every 8 . After 2 administrations 8 weeks apart with $\mathrm{UAS} 7 \leq 6$, stopping omalizumab was tried.

Adverse reactions were monitored after each omalizumab administration for immediate reactions (150 minutes for the first 3 administrations and 60 minutes thereafter) and late reactions (by reviewing the patients' urticaria diary).

Statistical analyses of the data were performed using SPSS software version 22.0 (IBM Corporation, New York, USA): descriptive statistics, Mann-Whitney tests, chi-square test, generalized linear model using a gamma distribution with log link function and a working correlation matrix with a autoregressive model of 1 st order structure to evaluate the UAS and UAS7 scores. A p value $<0.05$ was considered significant.

Consent from the Ethics Committee and Hospital Administration was obtained (Ref. 628/15, Comissão de Ética do Centro Académico de Medicina de Lisboa).

\section{Results}

Data is summed-up in table $\mathbf{1}$ and $\mathbf{2}$.

Twenty-six patients were included, 3 with CIndU ( 2 with delayed pressure urticaria and 1 with heat urticaria) and 23 with CSU. The age of urticaria onset was $38 \pm 15$ years in CSU and $57 \pm 12$ years in CIndU patients $(\mathrm{p}<0.05)$.

Thyroid autoantibodies were found in 7 (30\%) of the $23 \mathrm{CSU}$ patients; but only 1 was symptomatic with hypothyroidism (due to Hashimoto's thyroiditis). ASST was performed in 15 CSU patients and was positive in $9(60 \%)$. The remaining could not stop anti-histamines to perform the test.

Atopic comorbidities in CSU patients were present in $12 \mathrm{pa}-$ tients (52\%): 10 (43\%) had asthma and/or allergic rhinitis, 3 (13\%) had drug allergy and 2 (9\%) had food allergy. In CIndU patients, 1 had asthma, allergic rhinitis and food allergy.

Previous failed therapies to control urticaria were: immunoglobulin IgG in 1 patient with CIndU and 4 with CSU; cyclosporine in 3 patients with CSU and azathioprine in 1 patient with CSU. Prior to omalizumab, all patients were medicated with montelukast, nsAH 4 times/day and systemic oral corticosteroids. The initial corticosteroid dose was $1 \mathrm{mg} / \mathrm{kg} /$ day. The dose was subsequently tapered to the lowest dose possible, to maintain an equilibrium between maximum control of urticaria symptoms and the lowest 
side-effects. The final daily dose varied between 10 and $25 \mathrm{mg}$. Additionally, 1 (33\%) with CIndU and 15 (65\%) with CSU were medicated with $\mathrm{H} 2$-antihistamine. After omalizumab, no patient required systemic oral corticosteroids. By the end of this study, thirteen (57\%) CSU patients took nsAH only as SOS; $3(100 \%)$ with CIndU and 10 (43\%) with CSU took 1 to 2 nsAH daily. One (33\%) patient with CIndU and 3 (15\%) with CSU were medicated with montelukast due to respiratory atopic comorbidities.

Urticaria activity was measured with the UAS and UAS7 scores during the first 12 months of therapy and evaluated using generalized linear models (figure $\mathbf{1}$ and $\mathbf{2}$ ). CIndU patients' UAS/ UAS7 score prior to omalizumab initiation averaged $4.7 \pm 1.2$ / $33.7 \pm 1.9$; after 12 months of omalizumab, the score averaged 0 $\pm 0 / 0 \pm 0$. CSU patients' UAS/UAS7 score prior to omalizum$\mathrm{ab}$ initiation averaged $4.7 \pm 1.5 / 33.1 \pm 9.1$; after 12 months of omalizumab, the score averaged $0.8 \pm 0.9 / 1.3 \pm 2.2$. The UAS and UAS7 values pior to omalizumab show urticaria activity whilst the patients were on montelukast, nsAH 4 times/day and systemic oral corticosteroids.

CIndU and CSU patients had a reduction of the UAS score per omalizumab administration of $16 \%$ (both with $\mathrm{p}<0.001$ ). Using the UAS 7 score, CIndU patients had a reduction of the score per omalizumab administration of $15 \%(\mathrm{p}<0.001)$ and CSU patients a $20 \%$ reduction $(\mathrm{p}<0.001)$.

The number of sessions of omalizumab needed to achieve UAS $=0$ averaged 4 (CIndU) and 5 (CSU).

The QoL score at baseline in CIndU patients had a median of 18.5 (minimum 9, maximum 28) and in CSU patients had a median of 19 (minimum 6, maximum 28, interquartile range 8). After 6-12 months of omalizumab treatment, the QoL score in CIndU had a median of 0.0 (minimum 0 , maximum 0 ) and in CSU had a median of 0.0 (minimum 0 , maximum 6 , inter-

Table 1 - Comparison between CIndU and CSU patients' characteristics.

\begin{tabular}{|c|c|c|c|c|c|c|c|}
\hline & \multicolumn{3}{|c|}{ CIndU } & \multicolumn{3}{|c|}{ CSU } & \multirow[b]{2}{*}{$p$ value } \\
\hline & $A \pm S D$ & $\begin{array}{l}\text { M (min, max, } \\
I Q R)\end{array}$ & $\begin{array}{c}\text { normality } \\
\text { test }\end{array}$ & $A \pm S D$ & $\begin{array}{l}\text { M (min, max, } \\
\text { IQR) }\end{array}$ & $\begin{array}{c}\text { normality } \\
\text { test }\end{array}$ & \\
\hline $\begin{array}{l}\text { age of urticaria onset } \\
\text { (years) }\end{array}$ & $57 \pm 11.9$ & $50(46,56,-)$ & 0.363 & $38 \pm 14.7$ & $38(15,77,12)$ & 0.016 & $0.041(\mathrm{M})$ \\
\hline $\begin{array}{l}\text { age of omalizumab } \\
\text { start (years) }\end{array}$ & $54 \pm 10.6$ & $53(48,70,-)$ & 0.417 & $43.3 \pm 13.3$ & $43(23,80,11)$ & 0.025 & $0.052(\mathrm{M})$ \\
\hline $\begin{array}{l}\text { time between urticaria } \\
\text { onset and omalizumab } \\
\text { start (years) }\end{array}$ & $2.7 \pm 1.5$ & $3(2,4,-)$ & 1 & $5.2 \pm 5.7$ & $4(3,28,6)$ & 0.000 & $0.442(\mathrm{M})$ \\
\hline $\begin{array}{l}\text { duration of omalizum- } \\
\text { ab treatment (months) }\end{array}$ & $29.3 \pm 15.4$ & $21(18,46,-)$ & 0.187 & $29.7 \pm 20.9$ & $30(5,71,38)$ & 0.036 & $0.085(\mathrm{M})$ \\
\hline $\begin{array}{l}\text { total serum IgE } \\
(\mathrm{kU} / \mathrm{L})\end{array}$ & $76 \pm 19$ & $73(58.5,96,-)$ & 0.751 & $260 \pm 446$ & $\begin{array}{c}106 \\
(3.5,1840,243)\end{array}$ & $<0.001$ & $0.830(\mathrm{M})$ \\
\hline $\begin{array}{l}\text { number of sessions of } \\
\text { omalizumab adminis- } \\
\text { tration until UAS =0 } \\
\text { was achieved }\end{array}$ & $3.7 \pm 0.6$ & $4(3,4,-)$ & - & $4.7 \pm 3.6$ & $2.0(1,23,3)$ & $<0.001$ & $0.442(\mathrm{M})$ \\
\hline DLQI baseline score & $18.5 \pm 13.4$ & $18.5(9,28,-)$ & - & $18.2 \pm 6$ & $19(6,28,8)$ & 0.558 & $1(\mathrm{M})$ \\
\hline DLQI final score & $0 \pm 0$ & $0(0,0,-)$ & - & $0.7 \pm 1.4$ & $0.0(0,6,1)$ & $<0.001$ & $0.54(\mathrm{M})$ \\
\hline & \multicolumn{3}{|c|}{ percentage } & \multicolumn{4}{|c|}{ percentage } \\
\hline female gender & \multicolumn{3}{|c|}{$33 \%(\mathrm{n}=1)$} & \multicolumn{4}{|c|}{$87 \%(\mathrm{n}=20)$} \\
\hline $\begin{array}{l}\text { positive autologous } \\
\text { serum skin test }\end{array}$ & & \multicolumn{4}{|c|}{$60 \%$ (9 out of 15 patients) } \\
\hline anti-thyroid antibodies & \multicolumn{3}{|c|}{-} & \multicolumn{4}{|c|}{$30 \%$ (7 out of 23 patients) } \\
\hline
\end{tabular}

CSU, Chronic Spontaneous Urticaria; CIndU, Chronic Induced Urticaria; A \pm SD, Average \pm Standard Deviation; M (min, max, IQR), median value (minimum, maximum, Interquartile range); M, Mann-Whitney test. 
Table 2 - Data comparison between different studies.

\begin{tabular}{|c|c|c|c|c|c|}
\hline & Marcelino et al. & Silva et al. & Har et al. & Savic et al. & Metz et al. \\
\hline females & $21 / 26(81 \%)$ & $6 / 7(86 \%)$ & $5 / 10(50 \%)$ & $36 / 46(78 \%)$ & $\mathrm{U}$ \\
\hline CU duration & $\begin{array}{l}\text { CIndU } 2.7 \text { years } \\
\text { CSU } 5.2 \text { years }\end{array}$ & 7 years & 4 years & $\begin{array}{l}36 \% 1-5 \text { years } \\
38 \% 5-10 \text { years } \\
26 \%>10 \text { years }\end{array}$ & $\mathrm{U}$ \\
\hline average baseline $\operatorname{IgE}$ & $\begin{array}{l}\text { CIndU } 76 \mathrm{kU} / \mathrm{L} \\
\text { CSU } 260 \mathrm{kU} / \mathrm{L}\end{array}$ & $162 \mathrm{kU} / \mathrm{L}$ & $417 \mathrm{kU} / \mathrm{L}$ & U & $\mathrm{U}$ \\
\hline responded to omalizumab & $26 / 26(100 \%)$ & $7 / 7(100 \%)$ & $10 / 17(59 \%)$ & $27 / 36(75 \%)$ & $\mathrm{U}$ \\
\hline partial responders to omalizumab & $\begin{array}{l}\text { CIndU 2/3 } \\
(66 \%) \\
\text { CSU 12/23 } \\
(52 \%)\end{array}$ & $\mathrm{U}$ & $2 / 10(20 \%)$ & $12 / 36(33 \%)$ & $\mathrm{U}$ \\
\hline complete responders to omalizumab & $\begin{array}{c}\text { CIndU } 0(0 \%) \\
\text { CSU } 11 / 23 \\
(48 \%)\end{array}$ & $7 / 7(100 \%)$ & $8 / 10(80 \%)$ & $15 / 36(42 \%)$ & $\mathrm{U}$ \\
\hline omalizumab dependent $^{1}$ & $\begin{array}{c}\text { CIndU } 1 / 3 \\
(33 \%) \\
\text { CSU } 4 / 23(17 \%) \\
\end{array}$ & $1 / 7(14 \%)$ & $9 / 10(90 \%)$ & $\mathrm{U}$ & $\mathrm{U}$ \\
\hline non omalizumab dependent & $\begin{array}{c}\text { CIndU } 0(0 \%) \\
\text { CSU } 7 / 23(30 \%)\end{array}$ & $6 / 7(86 \%)$ & $1 / 10(10 \%)$ & $\mathrm{U}$ & $\mathrm{U}$ \\
\hline same efficacy when restarting omalizumab? & yes & yes & yes & $\mathrm{U}$ & yes \\
\hline longest omalizumab therapy duration & 73 months & 40 months & 112 months & $\mathrm{U}$ & $\mathrm{U}$ \\
\hline adverse effects reported & none & none & none & $\begin{array}{l}36 \text { events in- } \\
\text { volving 37\% of } \\
\text { patients }\end{array}$ & U \\
\hline DLQI baseline / after omalizumab & $\begin{array}{c}\text { CIndU } 18.5 \pm 13 \\
/ 0 \pm 0 \\
\text { CSU } 18.2 \pm 6 / \\
0.7 \pm 1\end{array}$ & $\mathrm{U}$ & $\mathrm{U}$ & $\begin{aligned} 19.5 & \pm 5.2 / 3.2 \\
& \pm 5.2\end{aligned}$ & $\mathrm{U}$ \\
\hline
\end{tabular}

${ }^{1}$ Described as patients who had symptom recurrence when spacing of administrations or discontinuation was tried. U, Unknown; DLQI, Dermatology Life Quality Index.

quartile range 1). The difference between initial e final median values was statistically significant $(\mathrm{p}<0.001)$ in CSU.

All CIndU patients were still on omalizumab by the end of this study. Their average treatment duration was $29 \pm 15$ months (min 19, max 46). Two patients were classified as partial responders and 1 as a complete responder. The complete responder was classified as omalizumab-dependent, because he reinitiated urticaria after stopping omalizumab. Reinitiating omalizumab controlled the urticaria.

Sixteen CSU patients were still on omalizumab by the end of this study. Their average treatment duration was $30 \pm 23$ months ( $\min 6, \max 72$ ). Of the 16, 12 had controlled urticaria, but were still on the stepping down process of other medication (as anti-histamines) and, because of that, were classified by the end of this study as partial responders. The remaining 4, were complete responders. However, because they reinitiated urticaria after stopping omalizumab and required reinitiating omalizumab to control the urticaria, they were classified as omalizumab-dependent. It is important to emphasize the terms partial and complete responders are related to the need for medication other than omalizumab, not urticaria control (all the above mentioned patients had urticaria control defined as UAS7 < 6). Seven (30\%) CSU patients had stopped omalizumab by the end of this study. These patients achieved urticaria control and stopped omalizumab without relapsing. Therefore, they were classified as complete responders and non omalizumab-dependent. Their treat- 
Figure 1 - UAS and UAS7 score progression in CIndU patients. A statistical analysis of the patients' UAS scores progression was performed and the corresponding generalized linear model was plotted. Patients had a reduction of the UAS score of $16 \%$ per omalizumab administration $(p<0.001)$ and of the UAS7 score of $15 \%$ per omalizumab administration $(p<0.001)$. Regression = generalized linear model.
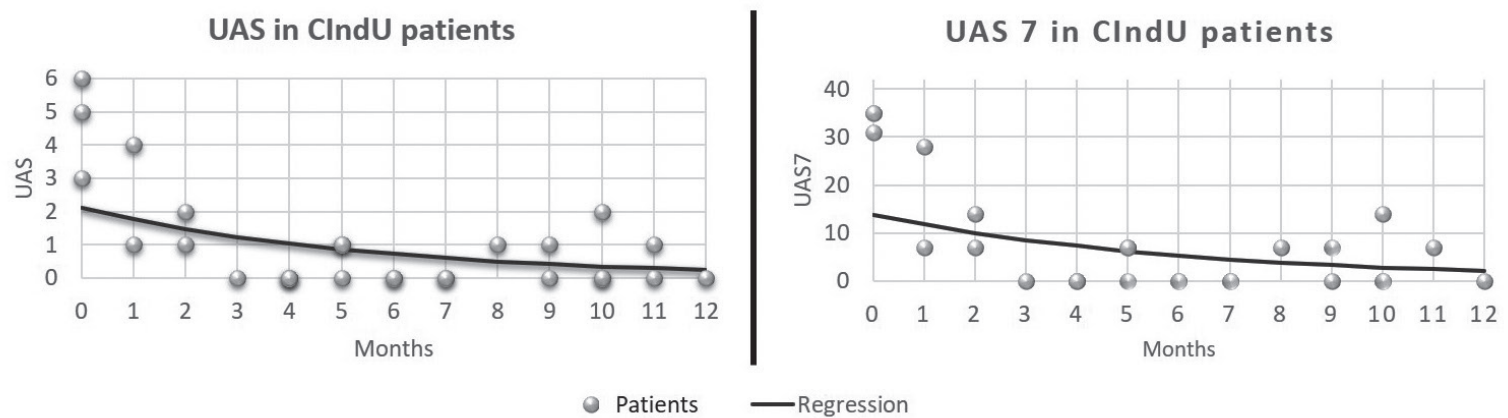

Figure 2 - UAS and UAS7 score progression in CSU patients. A statistical analysis of the patients' UAS scores progression was performed and the corresponding generalized linear model was plotted. Patients had a reduction of the UAS score of $16 \%$ per omalizumab administration $(p<0.001)$ and of the UAS7 score of $20 \%$ per omalizumab administration $(p<0.001)$. Regression = generalized linear model.

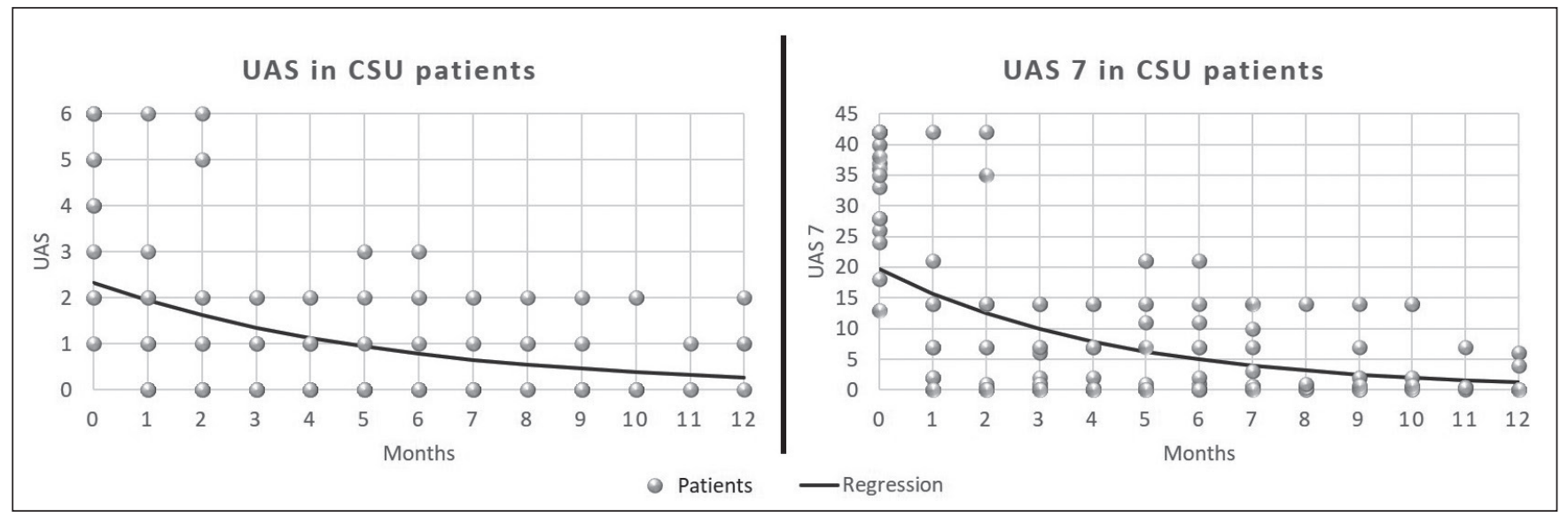

ment duration averaged $30 \pm 18$ months ( $\min 6, \max 49)$.

All patients who had to restart omalizumab or shorten back the administrations, had no lessening of effect. There were no non-responders in our population.

During the 73 months of omalizumab use, neither systemic immediate reactions were observed, nor late adverse side-effects attributed to omalizumab.

\section{Discussion}

Omalizumab is a recombinant humanized monoclonal anti-IgE IgG antibody. By sequestering free IgE, it prevents $\operatorname{IgE}$ binding to FceRI on the surface of mast cells and basophils. It may also indirectly down-regulate FcRI receptors, de-sensitize and raise the thresholds of mast cells and basophile degranulation and reduce the secretion of pro-inflammatory mediators $(18,19)$. In 2014, omalizumab was licensed as add-on therapy for CSU in patients older than 12 years of age (20). Because it was only recently approved, little is known about the long-term effects of this therapy. Most data comes from small case reports $(17,18,21)$. Even less is known about when and if omalizumab can be discontinued and there is no consensus regarding duration of omalizumab treatment in CSU. This is extremely important, as omalizumab is a very expensive therapy (17).

In our study, patients had severe urticaria. This can be observed by both CSU and CIndU patients showing an average baseline 
(before starting omalizumab) UAS7 score above 30. Some isolated patients had lower UAS7 scores, but were on high levels of oral corticosteroids (corticosteroid-dependent), which they could not sustain for long periods of time. Other patients, also with lower UAS7 scores, had very high DLQI scores and had these scores despite being medicated with montelukast, nsAH 4 times/day and systemic oral corticosteroids. Therefore, these patients were considered to have a severe enough urticaria to justify starting omalizumab.

In line with what is described in literature $(1,2)$ and in a similar study (18), our CSU patients had a female predominance. In agreement with other studies, our patients tried immune-modulating therapies prior to omalizumab (immunoglobulin $\operatorname{IgG}$ in 1 patient with CIndU and 4 with CSU; cyclosporine in 3 patients with CSU and azathioprine in 1 patient with CSU), with limited or no effect $(17,18,21-23)$. This lack of response did not predict lack of response to omalizumab. In addition, our patients were treated daily with montelukast, nsAH 4 times/day, $\mathrm{H} 2$-antihistamine (many of them) and systemic corticosteroids. This highlights the importance of omalizumab in weaning off other control therapies, especially corticosteroids, whose longterm use should be avoided.

Our CSU patients had a tendency for urticaria onset at an earlier age than CIndU patients. The reason for this finding is unknown. Our patients had a high baseline total serum IgE (table 1). Based on our data, Silva et al. (21) and Savic et al. (18), CU patients seem to have a tendency for elevated total serum IgE. As far as the authors are aware, no other publication has applied generalized linear models to study the progression of the urticaria activity score in response to omalizumab. This permitted to calculate, with statistical significance $(p<0.001)$, a decrease of the urticaria activity scores UAS and UAS7 between $15 \%$ and 20\% with each omalizumab administration (figure $\mathbf{1}$ and 2). There was no significant difference between the CSU and CIndU groups. It is also interesting to observe that, with omalizumab, this decline in the urticaria activity scores occurred even though patients were simultaneously weaning off other control therapy. This may suggest that omalizumab is more important as a control therapy than other oral control therapies.

Given the impact in patients' QoL, current guidelines propose the use of patient reported outcomes (1). Because the CU-QoL questionnaire is not validated for the Portuguese language, the authors used the validated DLQI. The QoL improvement was manifest in both CIndU and CSU patients. These results are similar to those reported by Savic et al. (18) who had a baseline score of $19.5 \pm 2$ (very similar to our patients) and who showed a $75 \%$ reduction in DLQI scores with omalizumab treatment (table 2).

The authors concur that the 6-month time limit is arbitrary and other time limits could be proposed to make the decision of response or lack of response to omalizumab. This practice was implemented to give enough time to evaluate the response of patients to omalizumab. Published data shows there are two types of response to omalizumab: fast responders and late responders. $(24,25)$ Time is needed to identify these late responders and not incorrectly classify them as non-responders. Because all patients go through this 6-month "trial" phase, no patient who could have been classified as non-responder was excluded from this study due to this time limit.

All our patients responded to omalizumab (there were no non-responders). This response rate is similar to previous data from our center reported by Silva et al. (21), but higher than that reported by Har et al. (10 out of 17 patients) (17) and Savic et al. (27 out of 36 patients) (18). Overall, approximately $41-48 \%$ of patients in clinical trials $(3-5)$ and $12-23 \%$ in "real-world clinical setting" (26-31) do not have a complete or significant response to omalizumab therapy.

The absence of non-responders is puzzling and was investigated. The argument these patients may have had less severe urticarias which might not have needed omalizumab is not in accordance with their clinical histories and the drugs the patients were taking and under which they still maintained high scores of UAS7 and DLQI. Another argument may be that it is due to the low number of CSU patients (23) included in this study. With time, as more patients start omalizumab, non-responders would appear. In addition to this, our department's 6-month "trial" period may also have had influence. As already stated, reports suggest there are two kinds of response to omalizumab, fast responders and late responders $(32,33)$. Which means, they only respond after several months of therapy. The percentage of non-responding patients in the clinical trials was calculated after 12 to 24 weeks of omalizumab. Therefore, some of the late responders could have been erroneously classified as non-responders. Consequently, because our 6-month time limit eliminates this bias, a lower rate of non-responders in our study could be expected. However, this is an important oddity of this study and further research is needed.

A key clinical feature is the type of response. Seventy-five percent of patients have a partial response; while $25 \%$ have a complete response. Of those, only $30 \%$ remain symptom free after omalizumab was discontinued; the others are omalizumab-dependent. This is very important, because no study has shown for how long this therapy can, safely, be maintained.

Some patients achieved remission and omalizumab could be stopped. Therefore, discontinuation should always be tried as successful remission is possible. Questions remain concerning how long omalizumab should be used until a successful discontinuation can be achieved. In our patients who achieved remission free of omalizumab, the average treatment duration was 30 \pm 18 months. 
Another important finding in our cohort, also shown by Metz et al. (32), is that there seems to be no loss of efficacy when reinitiating omalizumab after it has been discontinued.

In our study, patients were on omalizumab for up to 73 months with no apparent side-effects or loss of efficacy. Its good safety profile has been shown in the short term in various studies, with a recent meta-analysis of randomized clinical trials showing a similar rate of adverse events in the omalizumab and placebo groups (32). In a previous study by Silva et al. (21) and in our study, no adverse effects were reported with the long-term use. The authors believe that these results are comparable to the findings by Savic et al. (18) who reported 36 adverse events (involving 37\% of the patients), but which were mostly skin reactions whose manifestation closely resembled CSU symptoms and 2 events (pregnancy) completely unrelated to omalizumab.

The limitations of this study are: it is a retrospective study, few patients were included and we grouped different types of CIndU in the same group. However, considering the statistical significant results obtained, our main objective appears to have been accomplished. Nonetheless, more studies with a greater number of patients are required before any generalization of these results can be made.

\section{Conclusions}

In our cohort, omalizumab was a safe and effective therapy, both in CIndU and CSU. This is evident by the lack of severe side effects and the significant improvement of the QoL and Urticaria Activity Scores.

In line with other publications, our CSU patients were predominantly female and our $\mathrm{CU}$ patients had a high baseline total serum $\operatorname{IgE}$.

Seven $(30 \%)$ of our patients achieved urticaria control (UAS7 $\leq$ $6)$ and stopped omalizumab and all other medication without relapsing, showing disease remission. Therefore, an attempt to stop omalizumab should be considered, as remission is possible.

\section{Patient consent}

Obtained.

\section{Conflict of interest}

Ana Célia Costa M.D. is currently Principal investigator at Hospital de Santa Maria CHLN E.P.E., as part of the "AWARE" study, supported by Novartis Pharmaceuticals Corporation. Ana Célia Costa M.D. and Manuel Pereira-Barbosa M.D. are currently Principal investigators at Hospital de Santa Maria CHLN E.P.E., as part of the "Exploitation of the Basophil Activation Test (BAT) as a method for Xolair (omalizumab) treat- ment effectiveness in Chronic Spontaneous Urticaria (CSU)" study supported by Novartis Pharmaceuticals Corporation.

All authors consider that there are no other financial or personal relationship which could result in a conflict of interest with regard to the published article.

\section{References}

1. Zuberbier T, Aberer W, Asero R, Bindslev-Jensen C, Brzoza Z, Canonica GW, Church MK, Ensina LF, Giménez-Arnau A, Godse K, Gonçalo M, Grattan C, Hebert J, Hide M, Kaplan A, Kapp A, Abdul Latiff AH, Mathelier-Fusade P, Metz M, Nast A, Saini SS, Sánchez-Borges M, Schmid-Grendelmeier P, Simons FE, Staubach P, Sussman G, Toubi E, Vena GA, Wedi B, Zhu XJ, Maurer M; European Academy of Allergy and Clinical Immunology; Global Allergy and Asthma European Network; European Dermatology Forum; World Allergy Organization. The EAACI/GA(2) LEN/ $\mathrm{EDF} / \mathrm{WAO}$ Guideline for the definition, classification, diagnosis, and management of urticaria: the 2013 revision and update. Allergy 2014; 69(7):868-87.

2. Maurer M, Weller K, Bindslev-Jensen C, Giménez-Arnau A, Bousquet PJ, Bousquet J, Canonica GW, Church MK, Godse KV, Grattan CE, Greaves MW, Hide M, Kalogeromitros D, Kaplan AP, Saini SS, Zhu $\mathrm{XJ}$, Zuberbier T. Unmet clinical needs in chronic spontaneous urticaria. A GA2LEN task force report. Allergy 2011; 66(3):317-30.

3. Saini SS, Bindslev-Jensen C, Maurer M, Grob JJ, Bülbül Baskan E, Bradley MS, Canvin J, Rahmaoui A, Georgiou P, Alpan O, Spector S, Rosén K. Efficacy and Safety of Omalizumab in Patients with Chronic Idiopathic/Spontaneous Urticaria who Remain Symptomatic on H1 Antihistamines: A Randomized, Placebo-Controlled Study. J Invest Dermatol 2015; 135(3):925.

4. Maurer M, Rosén K, Hsieh HJ, Saini S, Grattan C, Gimenéz-Arnau A, Agarwal S, Doyle R, Canvin J, Kaplan A, Casale T. Omalizumab for the treatment of chronic idiopathic or spontaneous urticaria. N Engl J Med 2013; 368(24):2340-1.

5. Kaplan A, Ledford D, Ashby M, Canvin J, Zazzali JL, Conner E, Veith J, Kamath N, Staubach P, Jakob T, Stirling RG, Kuna P, Berger W, Maurer M, Rosén K. Omalizumab in patients with symptomatic chronic idiopathic/spontaneous urticaria despite standard combination therapy. J Allergy Clin Immunol 2013; 132(1):101-9.

6. Krause K, Ardelean E, Kessler B, Magerl M, Metz M, Siebenhaar F, Weller K, Worm M, Zuberbier T, Maurer M. Antihistamine-resistant urticaria factitial successfully treated with anti-immunoglobulin E therapy. Allergy 2010; 65(11):1494-5.

7. Metz M, Altrichter S, Ardelean E, Kessler B, Krause K, Magerl M, Siebenhaar F, Weller K, Zuberbier T, Maurer M. Anti-immunoglobulin $\mathrm{E}$ treatment of patients with recalcitrant physical urticaria. Int Arch Allergy Immunol 2011; 154(2):177-80.

8. Metz M, Bergmann P, Zuberbier T, Maurer M. Successful treatment of cholinergic urticaria with anti-immunoglobulin E therapy. Allergy 2008; 63(2):247-9.

9. Metz M, Ohanyan T, Church MK, Maurer M. Retreatment with omalizumab results in rapid remission in chronic spontaneous and inducible urticaria. JAMA Dermatol 2014; 150(3):288-90.

10. Güzelbey O, Ardelean E, Magerl M, Zuberbier T, Maurer M, Metz M. Successful treatment of solar urticaria with anti-immunoglobulin E therapy. Allergy 2008; 63(11):1563-5. 
11. Sussman G, Hébert J, Barron C, Bian J, Caron-Guay RM, Laflamme S, Stern S. Real-life experiences with omalizumab for the treatment of chronic urticaria. Ann Allergy Asthma Immunol 2014; 112(2):170-4.

12. Vieira Dos Santos R, Locks Bidese B, Rabello de Souza J, Maurer M. Effects of omalizumab in a patient with three types of chronic urticaria. Br J Dermatol 2014; 170(2):469-71.

13. Boyce JA. Successful treatment of cold-induced urticaria/anaphylaxis with anti-IgE. J Allergy Clin Immunol 2006; 117(6):1415-8.

14. Brodská P, Schmid-Grendelmeier P. Treatment of severe cold contact urticaria with omalizumab: case reports. Case Rep Dermatol 2012; 4(3):275-80.

15. Waibel KH, Reese DA, Hamilton RG, Devillez RL. Partial improvement of solar urticaria after omalizumab. J Allergy Clin Immunol 2010; 125(2):490-1.

16. Bindslev-Jensen C, Skov PS. Efficacy of omalizumab in delayed pressure urticaria: a case report. Allergy 2010; 65(1):138-9.

17. Har D, Patel S, Khan DA. Outcomes of using omalizumab for more than 1 year in refractory chronic urticaria. Ann Allergy Asthma Immunol 2015; 115(2):126-9.

18. Savic S, Marsland A, McKay D, Ardern-Jones MR, Leslie T, Somenzi O, Baldock L, Grattan C. Retrospective case note review of chronic spontaneous urticaria outcomes and adverse effects in patients treated with omalizumab or ciclosporin in UK secondary care. Allergy Asthma Clin Immunol 2015; 11(1):21.

19. Zuberbier T, Maurer M. omalizumab for the treatment of chronic urticaria. Expert Rev Clin Immunol 2015; 11(2):171-80.

20. Novartis Pharmaceuticals UK Ltd. Summary of product characteristics Xolair $150 \mathrm{mg}$ solution for injection. http://www.medicines. org.uk/emc/medicine/24912/SPC/Xolair+150mg+Solution+for+Injection/. Accessed 02 Dec 2015

21. Silva PM, Costa AC, Mendes A, Barbosa MP. Long-term efficacy of omalizumab in seven patients with treatment-resistant chronic spontaneous urticaria. Allergol Immunopathol (Madr) 2015; 43(2):168-73.

22. Casale TB, Bernstein JA, Maurer M, Saini SS, Trzaskoma B, Chen H, Grattan CE, Gimenéz-Arnau A, Kaplan AP, Rosén K. Similar Efficacy with Omalizumab in Chronic Idiopathic/Spontaneous Urticaria Despite Different Background Therapy. J Allergy Clin Immunol Pract 2015; 3(5):743-50.

23. Kaplan A, Ferrer M, Bernstein JA, Antonova E, Trzaskoma B, Raimundo K, Rosén K, Omachi TA, Khalil S, Zazzali JL. Timing and duration of omalizumab response in patients with chronic idiopathic/ spontaneous urticaria. J Allergy Clin Immunol 2016; 137(2):474-81.

24. Gericke J, Metz M, Ohanyan T, Weller K, Altrichter S, Skov PS, Falkencrone S, Brand J, Kromminga A, Hawro T, Church MK, Maurer M. Serum autoreactivity predicts time to response to omalizumab therapy in chronic spontaneous urticaria. J Allergy Clin Immunol 2017; 139(3):1059-61

25. Asero R, Tedeschi A, Marzano AV, Cugno M. Chronic urticaria: a focus on pathogenesis. F1000Res 2017; 6:1095.

26. Ertas R, Ozyurt K, Ozlu E, Ulas Y, Avci A, Atasoy M, Hawro T, Maurer M. Increased IgE levels are linked to faster relapse in patients with omalizumab-discontinued chronic spontaneous urticaria. J Allergy Clin Immunol 2017; 140(6):1749-51.

27. Deza G, Bertolín-Colilla M, Pujol RM, Curto-Barredo L, Soto D, García M, Hernández P, Gimeno R, Giménez-Arnau AM. Basophil FceRI Expression in Chronic Spontaneous Urticaria: A Potential Immunological Predictor of Response to Omalizumab Therapy. Acta Derm Venereol 2017; 97(6):698-704.

28. Gericke J, Metz M, Ohanyan T, Weller K, Altrichter S, Skov PS, Falkencrone S, Brand J, Kromminga A, Hawro T, Church MK, Maurer M. Serum autoreactivity predicts time to response to omalizumab therapy in chronic spontaneous urticaria. J Allergy Clin Immunol. 2017; 139(3):1059-61.

29. Labrador-Horrillo M, Valero A, Velasco M, Jáuregui I, Sastre J, Bartra J, Silvestre JF, Ortiz de Frutos J, Gimenez-Arnau A, Ferrer M. Efficacy of omalizumab in chronic spontaneous urticaria refractory to conventional therapy: analysis of 110 patients in real-life practice. Expert Opin Biol Ther 2013; 13(9):1225-8.

30. Metz M, Ohanyan T, Church MK, Maurer M. Omalizumab is an effective and rapidly acting therapy in difficult-to-treat chronic urticaria: a retrospective clinical analysis. J Dermatol Sci 2014; 73(1):57-62.

31. Rottem M, Segal R, Kivity S, Shamshines L, Graif Y, Shalit M, Kessel A, Panasoff J, Cohen S, Toubi E, Agmon-Levin N. Omalizumab therapy for chronic spontaneous urticaria: the Israeli experience. Isr Med Assoc J 2014; 16(8):487-90.

32. Metz M, Ohanyan T, Church MK, Maurer M. Retreatment with omalizumab results in rapid remission in chronic spontaneous and inducible urticaria. JAMA Dermatol 2014; 150(3):288-90.

33. Zhao ZT, Ji CM, Yu WJ, Meng L, Hawro T, Wei JF, Maurer M. Omalizumab for the treatment of chronic spontaneous urticaria: A meta-analysis of randomized clinical trials. J Allergy Clin Immunol. 2016; 137(6):1742-50. 